\title{
Emerging Demographic Transition in India
}

\author{
S. Sunitha \\ Assistant Professor, Department of Economics, \\ Nesamony Memorial Christian College, Kanyakumari, Tamil Nadu, India \\ E-Mail: ssunitha2014@gmail.com
}

\begin{abstract}
Demographics of India is remarkably diverse. India is the second most populous country in the world with more than one sixth of the world population. The stock of any population changes with time. There are three components of population changes which are fertility, mortality and migration. Socio economic phenomena of population development and their impact and differentials like urbanization, infant mortality rate, migration and causes of death are important to understand the population characteristics. It is observed that the growth of population depends on birth rate and death rates in India. During first phase birth rate as well as death rate was high. In the fourth phase birth rate and death rates are decline. It was also found that life expectancy at birth had been gradually increased in India. There is a need to coordinate the population policy with education policy. Employment generation programmes has been launched in the country to solve unemployment problem and mitigate rural unemployment.
\end{abstract}

Keywords: Demographic Transition, Population Policy, Population Explosion, Mortality, Fertility, Brain Drain and Life Expectancy

\section{INTRODUCTION}

In today's scenario population is said to be one of the major challenges faced by every country. The world population has risen from 5 billion in 1981 to seven billion in 2011 . Another eight billion will be added over in another 12 years time. This change is visible both in developed and developing countries. To understand this transition in population, it is important to concentrate on the demographic transition which means the shifts in birth and death rates that historically have occurred over a long period of time. The transition describes two trends. i) The decline in birth rates and the resultant decrease in the number of children and ii) The decline in death rates with better public health initiatives. This demographic transition necessitates new National Population Policy in India.

\section{A. Population Policy in India}

India is the second most populous country in the world, sustaining 16.7 per cent of the world population and 2.4 per cent of the world surface area. From 1871 onwards, when systematic decennial census was begun, we have a fairly correct assessment of the population. The population of the country was enumerated at 238.4 million in 1901. According to 2011 census, the population of India was 1210.1 million. In population, India is the second largest country in the world after China. The first private birth country clinic was opened in Bombay (now Mumbai) in 1925. The Mysore Government opened the first public birth control clinic in 1930. In 1932, the All India Women's conference recommended the opening of birth control clinics. In 1938, the National Planning Committee under the Chairmanship of Pandit Jawaharlal Nehru strongly supported family planning in the interest of social, economic and family happiness. The state should establish a policy to encourage these. The Bhore Committee recommended the provision of birth control services in 1946. India is the first country in the world to formulate a national official family planning programme in 1952, which was later expanded to encompass maternal and child health, family welfare and nutrition. The objective of the policy was reducing birth rate to the extent necessary to stabilize the population at a level consistent with the requirement of national economy.

Population policy in India has a history lasting more than 50 years. It speaks about the related issued and concerns as they affect the process of social and economic development and the well-being of people. The specific measures taken in population policies are schemes for women development, child welfare, minimum marriage age of girls, controlling the size of the population, rural-urban distribution, health awareness programmes for women, health and benefit schemes for women and children, birth and death rates, fertility rate etc. The measures are always taken for public interest and for the economic development of the country. The Government of India made new National population policy on $15^{\text {th }}$ February 2000 with a view to stabilize the population by $2040 \mathrm{AD}$. The policy motivates to encourage the two child norm. In this regard, the study necessitates to analyze the demographic features of India over a period of time

\section{B. Background of the Study}

Robert Thomas Malthus was a forerunner of analyzing population growth and economic development. He propounds that human species increase at geometric proportion and the arithmetic growth of means of subsistence contained the real meat of his argument in those days.

The theory of demographic transition helps to understand and analyze the change in volume of population. The saga of growth of population in India is almost in tune with the 
popular theory of demographic transition. Growth rate of India's population can be categorized into four phases. Demographers how developed theories on the basis of four phases of population growth. They are:

Phase I: 1901-1921 (Stagnant Population)

Phase II: 1921-1951 (Steady Growth)

Phase III: 1951-1981 (Rapid Growth) and

Phase IV: 1981-2011 (High growth with significant of slowing down)

\section{LITERATURE REVIEW}

William Joe, et al., (2015) in their study entitled "Demographic Transition, Savings, and Economic Growth in China and India" found that China has a significant association between dependency ratio and savings, whereas such an association is expected to emerge in India. Higher domestic savings and investments during the demographic dividend phase are critical to counter the adverse impact of population ageing and to ensure growth sustainability. James K (2017) in his study "Demographic Changes in India: Is the country prepared for the Challenge" highlighted that child marriages contribute to unskilled and unhealthy labor and pose an even greater health burden, which negatively affects the economy.

\section{STATEMENT OF THE PROBLEM}

Demographic change in India is opening up new economic opportunities. India's population has surpassed China where our country possesses the youngest population. This demographic change covers fertility, mortality, migration, size of the population and age structure. The effectiveness of such demographic change needs to be studied. It also becomes important to know the sort of changes that has been implemented in population policy. Awareness of the benefits of population policy for women, health awareness programmes for women, knowledge of insurance schemes, family commitments are said to be few factors mainly associated with demographic changes in India. There is controversial opinion regarding population growth growing population is viewed as favorable for the economy according to one school of thought. Population is a source of effective demand, invention, innovation, and entrepreneurship. Another school of thought contends that rising population exerts heavy pressure on government for provision of both social and economic infrastructure which has vast financial implications. Hence, the present study focuses on the changes in demographic features.

\section{OBJECTIVES OF THE STUDY}

The present study has the following specific objectives

1. To study the demographic changes in India.

2. To analyse the size, growth and structure of population, birth and death rates, infant mortality, fertility rate, life expectancy and brain drain rates in India.

\section{SCOPE OF THE STUDY}

Demographic transition is the changes in the population over a period of 1901 to 2017. This means shifts in birth and death rates have historically occurred over a period of time.

\section{ANALYSIS OF DEMOGRAPHIC FEATURES}

\section{A. Size, Growth and Structure of Population in India}

The 2011 Census enumerated the population of India at 1210.1 million. This rapid growing population put greater pressure on basic human need such as education, health facilities, water supply, nutrition and housing. The size, growth and structure of population in India are presented in Table I.



\begin{tabular}{|c|c|c|c|c|c|}
\hline $\begin{array}{c}\text { Census } \\
\text { Year }\end{array}$ & $\begin{array}{c}\text { Population } \\
\text { (in million) }\end{array}$ & $\begin{array}{c}\text { Decadal Variation } \\
\text { (in percent) }\end{array}$ & $\begin{array}{c}\text { Density of } \\
\text { Population } \\
\text { (per sq.km) }\end{array}$ & $\begin{array}{c}\text { Sex Ratio } \\
\text { (females per } \\
\text { 1000 males) }\end{array}$ & $\begin{array}{c}\text { Literacy } \\
\text { rate (in } \\
\text { per cent) }\end{array}$ \\
\hline 1901 & 238.4 & - & 77 & 972 & 5.35 \\
1911 & 252.1 & 5.75 & 82 & 964 & 5.92 \\
1921 & 251.3 & -0.31 & 81 & 955 & 9.16 \\
1931 & 279.0 & 11.00 & 90 & 950 & 9.50 \\
1941 & 318.7 & 14.22 & 103 & 945 & 16.10 \\
1951 & 361.1 & 13.31 & 117 & 946 & 18.33 \\
1961 & 439.2 & 21.51 & 142 & 941 & 28.30 \\
1971 & 548.2 & 24.80 & 177 & 930 & 34.48 \\
1981 & 683.3 & 24.66 & 216 & 934 & 43.56 \\
1991 & 846.6 & 23.87 & 324 & 927 & 52.21 \\
2001 & 1028.6 & 21.54 & 382 & 933 & 64.83 \\
2011 & 1210.1 & 17.64 & 455 & 940 & 74.04 \\
2017 & 1281.9 & - & 945 & - \\
\hline
\end{tabular}

Source: Government of India, Family Welfare Statistics in India 2009, Ministry of Health and Family Welfare,New Delhi, 2009;

Census of India 2001, Provisional Population Totals, Paper 1 of 2001, Series a, India 2001; Census of India 2011, Provisional Population Totals, India 2011; Government of India, Selected Socio- Economic Statistics in India, 2011, Ministry of Statistics and Programme Implementation, New Delhi, 2011; https//countryeconomy.com>India 
Table I reveals that Indian population has grown steadily from 1901, except for a decrease in 1921. The very slow increase in population between 1901 and 1921 was due to occurrences of epidemics like plaque, cholera, periodic famines and influenza epidemics. During 1931, the total population of India was 279 million, it increased to 361.1 million in 1951 and further increased to 1210.1 million 2011. The decadal growth of population was 5.75 in 1911 and negative $(-0.31)$ in 1921 .

After 1921, the growth rate increased. At the beginning of the twentieth century that is in 1901 the density of population of India was as 77 persons per square kilometer. It increased to 82 in 1911, and again it declined to 81 in 1921 and then steadily increased from one decade to another to reach 382 in 2011. High increase in density of population is a matter of great concern as it put immense pressure on our natural resources. Also it adversely affected the quality of life.

Sex ratio is a perfect way for finding the number of women in any country. It was 972 females per 1000 males in 1901 and thereafter showed continuous decline until 1941. There were 945 females per 1000 males in 1941. In 1951, there was a marginal increase of one point. According to the Census of India 2001, the sex ratio stood at 933 for the country as a whole. This is a welcome improvement from 1991 census which had 927 females for every male. The low sex ratio indicating a higher infant mortality reflects the preference for sons in the society. At the reproductive age, maternal mortality, female infanticide and change in gender ratio at birth adds to the high percentage of female deaths. As per Census 2011, there were 940 females per 1000 males which shown as upward trend from Census 2001. During the year 2017 the sex ratio was 945 per thousand males.

Literacy is a reasonably good indicator of development in a society. Literacy helps in the development of essential traits such as modernization, urbanization, industrialization, communication and commerce. The literacy rate starting from 1901 onwards show a consistent increase both for males and females. The literacy level rate in 1901 started with a low level of 5.35 per cent and steadily increased to reach a figure of 5.92 per cent in 1911. It further improved sharply to 18.33 per cent in 1951. By the Census of India 2011, the overall literacy rate of India was 74.04 per cent. Thus the increase in literacy rate observed during 20012011 in respect persons, have been the highest recorded in comparison to the earlier decades since 1901.

\section{B. Birth and Death Rates}

Mortality is the first key driver of population change in the demographic transition. The reduction of premature deaths is the crucial catalyst of demographic change. The natural growth rate refers to the difference between the birth and death rate. The growth of population depends on the birth and death rates. The natural growth rate of population in India is analysed with the help of figures given in Table II.
TABLE II BIRTH AND DEATH RATES IN INDIA 1901-11 To 2016-2017

\begin{tabular}{|c|c|c|c|}
\hline $\begin{array}{c}\text { Census } \\
\text { Year }\end{array}$ & $\begin{array}{c}\text { Birth Rate } \\
\text { (in per cent) }\end{array}$ & $\begin{array}{c}\text { Death Rate } \\
\text { (in per cent) }\end{array}$ & $\begin{array}{c}\text { Natural } \\
\text { Growth Rate } \\
\text { (BR-DR) }\end{array}$ \\
\hline $1901-11$ & 49.2 & 42.6 & 6.6 \\
$1911-21$ & 48.1 & 47.2 & 0.9 \\
$1921-31$ & 46.4 & 36.3 & 10.1 \\
$1931-41$ & 45.2 & 31.2 & 14.0 \\
$1941-51$ & 39.9 & 27.4 & 12.5 \\
$1951-61$ & 41.7 & 22.8 & 18.9 \\
$1961-71$ & 41.2 & 19.0 & 22.2 \\
$1971-81$ & 37.2 & 15.0 & 22.2 \\
$1981-91$ & 32.5 & 11.4 & 21.1 \\
$1991-2001$ & 24.8 & 8.9 & 15.9 \\
$2001-2011$ & 21.8 & 7.1 & 14.7 \\
$2016-2017$ & 18.8 & 7.3 & 11.7 \\
\hline \multicolumn{3}{|c|}{ Source: Same as Table I; https://www.indexmundi.com>India; } \\
\multicolumn{4}{|c}{ https://knoema.com.populationforecast }
\end{tabular}

Table II depicts that overall birth rate in the country. It came down from 49.2 per 1000 persons in 1901-11 to 39.9 in 1941-1951. In the year 1951-61 the birth rate was 41.7 persons per 1000 population. Thereafter, it decreased from 41.2 in 1961-71, to 32.5 in 1981-91 and further declined steeply to 21.8 per 1000 persons in 2001-2011. The reasons for the decline in birthrate are contraception oriented family planning programmes, economic and social factors like industrialization, increase in income levels, urbanization, literacy especially female literacy and the increase in the status of women. The death rate in India started to decline from 1921 onwards. The early reduction in death rate after 1921 was predominantly due to the control of famine and epidemics such as plaque and cholera. The death rate was estimated to 42.6 per 1000 persons in 1901-1911, it again increased to 47.2 per 1000 persons in 1911-21. The death rate started to decrease from 36.3 per 1000 persons in 192131 to 27.4 in $1941-51$ and then to 7.1 in $2001-2011$. The technological advancement and improved quality and coverage of health care resulted in a rapid fall in death rate from 27.4 in 1941-51 to 7.1 in 2001-2011.

The most important factor contributing to the very high growth rate of Indian population in recent years has been sudden and phenomenal fall in the death rate. But the fall in the birth rate has been comparatively low, so the gap between birth rate and death rate has widened from 18.9 per 1000 persons in 1951-61 to 22.22 in 1971-81. As a result, the rate of natural increase in population has been accelerating from year to year. It is easier to control mortality than fertility. However, during 1981-91, the natural increase in population decelerated marginally to 21 . per 1000 persons and 14.7 per 1000 persons in 2001-2011.

\section{Mortality and Fertility}

Mortality is the first key driver of population change in the demographic transition. Mortality transition is the reduction of premature deaths. It is the crucial catalyst of demographic change. The infant mortality rate is the most sensitive and widely used summary of mortality rate progress and improvement in population health. 
TABLE III INFANT MORTALITY RATE (IMR) AND TOTAL FERTILITY RATE IN INDIA $1971-2017$

\begin{tabular}{|c|c|c|}
\hline Year & $\begin{array}{c}\text { Infant Mortality } \\
\text { Rate (IMR) }\end{array}$ & $\begin{array}{c}\text { Total Fertility } \\
\text { Rate (TFR) }\end{array}$ \\
\hline 1971 & 129 & 5.2 \\
1981 & 110 & 4.5 \\
1991 & 80 & 3.6 \\
2001 & 66 & 3.1 \\
2011 & 44 & 2.4 \\
2017 & 30 & 2.3 \\
\hline
\end{tabular}

Source: Government of India, Family Welfare Statistics in India 2011 Ministry of Health and Family Welfare, New Delhi; https://timesofindia.indiatimes.com

Table III reveals data regarding infant mortality rate and total fertility rate in India during 1971 -2017. Infant mortality rate is an important indicator of the health status of the population. The IMR was 129 infant deaths per 1000 live births in 1971 and decreased to 30 in 2017. The reason for the sharper fall in the infant mortality rate was due to improvement in health and nutrition conditions of pregnant women. Incidence of low birth weight babies reduced, a level of immunization of mothers and children improved, birth interval increased to at least 36 months and pre and postnatal cares improved. The total fertility rate for India has shown a sharp declined from 5.2 in 1971 to 4.5 in 1981, 3.6 in 1991, 3.1 in 2001 and it further decline 2.3 in 2017. Fertility decline in India has been the effect of various socio economic developments as well as government sponsored family welfare programme. Rising levels of education, increase in female age of marriage, influence of mass media, economic development, gender empowerment, measure for equality, urbanization, diffusion of new ideas and decline in infant and child mortality have all contributed to the lowering of fertility.

\section{Life Expectancy at Birth}

It is important to note that India's present demography is also rapidly changing. Life expectancy has gone up considerably in recent years. The number of years for which people of a country expect to live at the time of birth is the average life expectancy of that country. It depends on the death rate and the age at the time of death. If the death rate is high or death occurs at an early age, the life expectancy of the people will be low. In the early years of $20^{\text {th }}$ century, the life expectancy of the people of India was deplorably low, as low as 25 years. It increased to 32 years in 1951, 41 years in 1961, 59 years in 1991, 67.01 years in 2011 and 68.8 in 2017. The improvement in life expectancy is closely tied to the control of epidemic and famines and the introduction of better medical technology, along with recent changes in socio economic conditions. It is noted that population growth has increased while life expectancy has also been gradually increased in India.

\section{E. Brain Drain}

The volume of international migration to this country due to partition of the country in 1947 was high. Large number of persons had migrated from both West Pakistan and East Pakistan. Later during the 1971 war a large influx of population was recorded from Bangladesh. The data on migration shows that in 2001 census, about 51 lakh persons in the country were migrants from across the international border. About 97 per cent of them were from the eight neighboring countries. Of these migrants, 30 lakh were from Bangladesh and 1 lakh from Sri Lanka. The volume of total migration had declined considerably over the decades since 1971. The number of migrants from other countries reduced to only 7.4 lakh during the last ten years at the 2001 census. In comparison to 1991, there is 31.6 per cent decline in international migration to India in 2001. This is due to substantial decline in the number of recent migration and death of earlier migrants due to old age. Investments in the education system and science and technology system as a whole resulted in the endowment of highly qualified human resources. As we approached 1960s and 1970s, skilled workforce started leaving country due to lack of opportunities. India witnessed brain drain in two phases.

The first phase came about immediately after independence in the 1940s and 1950s. The scientific elite under the leadership of Nehru made relentless efforts to bring back eminent Indian professionals from abroad to lead the newly created science institutions. The second one came about after liberal the economic reforms in 1991, the dynamism of Indian economy during 1990s after liberalization era offered a range of opportunities in high technology areas (ICT software, biotechnology space research and pharmaceuticals). This attracted some highly qualified professionals back into India during 1990s and is still continuing.

As per census 2011, migration between rural areas is more (47.4 per cent) followed by urban areas (22.6 per cent), rural and urban areas (22.1 per cent) and urban and rural areas (7.9 per cent). Between 2001 and 2011, rural to urban migration increased marginally from 21.8 per cent to 22.1 per cent and urban to urban migration increased from 15.2 per cent to 22.6 per cent. The share of family related migration (marriage) has increased from 28 per cent to 36 per cent between census 2001 and 2011. 50 per cent men move due to work. The share of work related migration decreases from 16 per cent to 13 per cent from 2001 census.

\section{FINDINGS OF THE STUDY}

As a result of the ongoing transition, India's population has increased from 238 million in 1901 to 1210 million in 2011 and 1281 million in 2017.

The pace was slow up to 1921, with some decline during the decade of 1911-21 but picked up after 1921 and accelerated after 1951. The latest census has shown a clear fall, to a decadal growth of 17.6 per cent and annual rate of 1.62 per cent. 
According to the Census of India 2001, the sex ratio stands at 933 for the country as a whole. This is a welcome to improvement from 1991 census which has 927 females for every male. As per Census 2011, there were 940 females per 1000 males which shows an upward trend from Census 2001.

The literacy rate in 1901 started with a low level of 5.35 per cent steadily increased to reach a figure of 5.92 per cent in 1911. It further improved sharply to 18.33 per cent in 1951 . As the Census of India 2011, the overall literacy rate of India is 74.04 per cent. Thus, the increase in literacy rate observed during 2001-2011 in respect of persons, have been the highest recorded in comparison to the earlier decades since 1901 .

The crude death rate was very high, over 40 per thousand during early years of the twentieth century but fell steadily below 40 in the 1920s, below 30 in the 1940s, and further below 20 after 1960s. It has been less than 10 since the 1990s.

The infant mortality rate was well over 100 per thousand through the 1970s but the latest figure for 2017 is 30 . Fertility was high in India in the past; with the Crude Birth Rate is the upper 40s (per thousand people) during the early part of the twentieth century. A steady fall is seen since the 1970s, with the Crude Birth Rate reaching 22.1 and the Total fertility rate 2.4 by 2011 . It is originally decline to fertility is lower in urban areas than rural, among the more educated than the less educated, among the rich and middle classes than the poor.

The life expectancy in India has increased from low of 20 years during 1911-20 to over 30 years during 1931-40, crossed 40 years during 1951-60, 50 years in the mid-1970s and 60 years in the early 1990s.

Every year, brilliant and intelligent people migrate to foreign countries in search of better job. India is not overproducing educated manpower, considering the needs of its vast population. At the same time, unemployment and underemployment is a cause to brain drain.

\section{CONCLUSION}

India is undergoing rapid demographic change for the past few decades. The demographic outlook of the country looks brighter, more equal, and will have many benefits. Indian family ties continue to be strong. Marriage remains nearly universal and divorce is rather rare. Moreover, care of the elderly is addressed mostly within the family. At the same time, resources within the family are scarce. The country has to make serious efforts to enhance the quality of life in all age groups through human capital improvement and skill level enhancement. Such efforts necessitate a huge public investment in education and health. India's highly privatized and compartmentalized health and education systems, which have very different opportunities for different economic classes, perpetuate these disparities instead of reducing them, in contrast to what health and education systems from public support have tended to do around the world. There is a need to coordinate the population policy with education policy. Employment generation programmes have been launched in the country to solve unemployment problem and mitigate rural unemployment.

\section{REFERENCES}

[1] Alok Ranjan. (1999). Fertility Transition in Indian States 1985-1999, Demography India, 26(1).

[2] Census of India. (2001). Provisional Population Totals, Paper 1 of 2001, Series 1, India.

[3] Census of India. (2001). Census Atlas of India 2001, Office of the Registrar General and Census Commissioner, New Delhi.

[4] Christopher, Z., Guilmoto \& Irudaya Rajan, S. (2002). District level estimates of fertility from India's 2001 census, Economic and Political Weekly, 37(7).

[5] Christopher, Z., Guilmoto \& Irudaya Rajan, S. (2005). Fertility transition in south India, Sage Publications, New Delhi.

[6] David E. Bloom (2011) Population dynamics in India and implications for economic growth, Program on the Global Demography of Aging, Working Paper 65, Harvard School of Public Health, Harvard University, Boston.

[7] Government of India. (1956). Second Five Year Plan (1956-1961), Planning Commission, New Delhi.

[8] Government of India. (2007). Family Welfare Statistics in India, Ministry of Health and Family Welfare, New Delhi.

[9] Government of India. (2009). Family Welfare Statistics in India 2009, Ministry of Health and Family Welfare, New Delhi.

[10] Government of India. (2008). Eleventh Five Year Plan (2007-2012), Planning Commission, New Delhi, 2.

[11] Government of India. (2011). Selected Socio-Economic Statistics India 2011, Ministry of Statistics and Programme Implementation, Central Statistics Office, Social Statistics Division, New Delhi.

[12] Irudaya Rajan, S., (2005). District level fertility estimates for Hindus and Muslims, Economic and Political Weekly, 40(5).

[13] Sankaran, S. (2009). Indian Economy, Margham Publications, Chennai, $5.9-5.29$.

[14] United Nations. (1999). World Population Prospects, United Nations Population Division, Department of International Economic and Social Affairs, New York

[15] United Nations. (2015). World Population Prospects, United Nations Population Division, Department of Economic and Social Affairs, New York, 2015.

[16] William Joe, Atish Kumar Dash \& Pradeep Agrawal. (2015). Demographic Transition, Savings, and Economic Growth in China and India IEG Working Paper 351, 1-16

[17] Retrieved from https//countryeconomy.com $>$ India.

[18] Retrieved from https://www.indexmundi.com>India;

[19] Retrieved from https://knoema.com.populationforecast.

[20] Retrieved from https://www.censusindia.gov.in. 